\section{Pemanfaatan Cloud Storage pada administrasi dan dokumentasi pelaksanaan pekerjaan konstruksi}

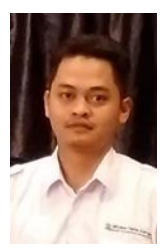

Administrasi pelaksanaan pekerjaan konstruksi yang masih menggunakan sistem konvesional yaitu semua data di hardcopy kan dan disimpan dalam lemari kantor mempunyai kendala saat data tersebut diperlukan cepat untuk ditampilkan. Penulis memanfatkan sistem Cloud Storage untuk melakukan penyimpanan datadata tersebut agar mempermudah dan mempercepat pengambilan data dan bisa dilakukan dimana saja
Lahir pada 4 januri 1988 menempuh jalur pendidikan Strata satu pada fakultas teknik jurusan teknik sipil sekarang bekerja sebagai konsultan individual pada satker PSPLP direktorat PLP dirjen Cipta Karya. buletinppi@ulm.ac.id

www.buletinppi.ulm.ac.id

\section{Pendahuluan}

Pelaksanaan Pekerjaan Konstruksi yang baik harus tertib dalam segala aspek yaitu tertib mutu, tertib waktu dan tertib administrasi. Pada saat ini penyimpanan data pelaksanaan pekerjaan konstruksi masih menggunakan system konvesional dimana data-data dibuat secara hardcopy. System tersebut memerlukan ruangan yang besar dan juga pada saat melakukan pencarian berkas akan kesulitan jika tidak teratur penempatannya atau data nya sudah lebih dari 2 atau 3 tahun

\section{Hasil Kerja}

Pengertian

Cloud Storage atau penyimpanan cloud adalah suatu media penyimpanan data secara online, yang nantinya data-data tersebut akan disimpan ke dalam sebuah server di internet. Karena datanya ada di internet, kita bisa dengan mudah mengakses data tersebut, tanpa harus membawa-bawa perangkat penyimpanan datanya.Penulis Mencoba Sistem Cloud Storage pada Pelaksanaan Pekerjaan di Satuan Kerja pengembangan system penyehatan lingkungan permukiman provins Kalimantan selatan. Pemilihan Server Cloud jatuh pada google Drive karena kapasitas ruang gratisnya yang besar yaitu $15 \mathrm{~Gb}$

\section{Implementasi}

Implementasi Sistem Cloud Storage yang sudah dilakukan pada seluruh paket pekerjaan di SATKER PSPLP Kalsel yaitu masing-masing paket pekerjaan memiliki akun google drive. Akun dan password tersebut hanya dimiliki oleh unsur satker dan unsur konsultan supervise. Pada google drive sudah dibuatkan folderfolder data untuk di isi dan di update. Updating berkas berkas administrasi di lakukan oleh unsur konsultan setiap minggu dan dimonitor oleh unsur satker

\section{Data Cloud Storage}

Folder-folder data pada Cloud Storage yang harus di isi dan diupdate dapat dilihat pada gambar di bawah ini

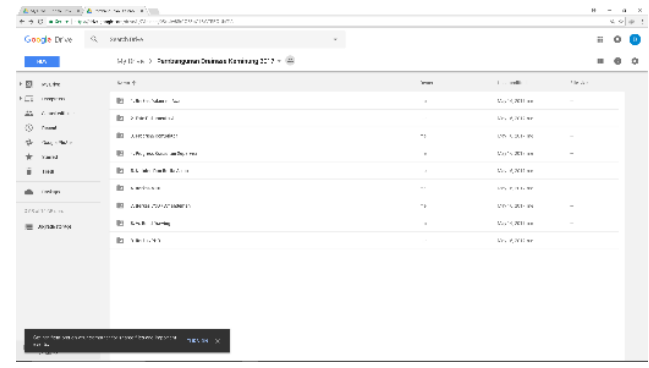

Folder yang konstan tiap minggu harus di update adalah dokumentasi foto dan progress pekerjaan, untuk pemberkasan berita acara, data hardcopy berita acara di scan kemudian di upload ke google drive

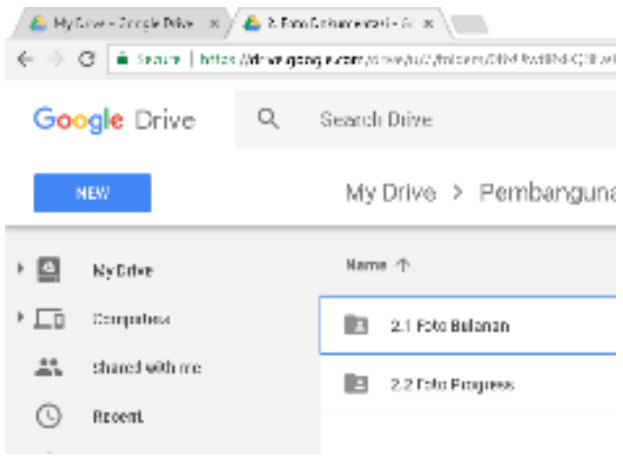

\section{Kesimpulan}

Penggunaan system cloud strorage pada dasarnya mempermudah semua pihak dalam penyimpanan datadata penting pekerjaan, baik untuk tahun berjalan ataupun tahun-tahun berikutnya jika data-data itu diperlukan secepatnya dan bisa dilihat dimana saja tanpa harus membuka berkas dikantor 
Buletin Profesi Insinyur 1(2) (2018) 1-7

\section{Ucapan Terimakasih}

Ucapan terima kasih kami sampiakan kepada Satuan kerja pengembangan system penyehatan lingkungan permukiman provinsi Kalimantan selatan yang telah memberikan kesempatan dalam mengimplementasikan system cloud storage ini 